\title{
LA CREACIÓN ARTÍSTICA COMO DISCURSO PROTEGIDO: EXPERIENCIAS COMPARADAS Y POSIBILIDADES ESPAÑOLAS
}

\author{
JOAQUÍN URÍAS \\ Profesor Titular de Derecho Constitucional \\ Universidad de Sevilla
}

\author{
TRC, núm. 46, 2020, pp. 343-370
}

ISSN 1139-5583

\section{SUMARIO}

I. Introducción. II. El valor de la creación como discurso protegido. III. Creación artística y ficción. IV. Conclusión.

\section{INTRODUCCIÓN}

El artículo 20.1.b) CE reconoce y garantiza el derecho a la producción y la creación artística, literaria, científica y técnica, dando carta de naturaleza a un derecho específico, centrado en la innovación, al que genéricamente puede aludirse como libertad de creación. En cuanto garantía del proceso creativo que da lugar a una obra intelectual, esta libertad protege tanto el momento de gestación de la obra — reforzado por la prohibición absoluta de censura previa - como la difusión del resultado del proceso creativo.

El reconocimiento autónomo de la libertad de creación no es una particularidad de la Constitución española. Bien al contrario, aparece en la mayoría de textos constitucionales europeos y muchos internacionales, aunque en ocasiones se pone en relación con otros derechos o valores, como la libertad de expresión en el párrafo tercero del art. 5 de la Ley Fundamental de Bonn, o incluso la educación a la manera del art. 33 de la Constitución Italiana ${ }^{1}$. En el ámbito

1 En Austria el art. 17.a conecta la libertad de creación con la transmisión del arte y su enseñanza; en Portugal el art. 42 recoge la difusión y se refiere a los derechos de autor. Suiza dedica el art. 20 a la libertad de investigación científica, conectada a la enseñanza y el 21 a la libertad de creación artística. El art. 33 de la 
internacional, el artículo 13 de la Carta de Derechos Fundamentales de la Unión Europea indica que «las artes y la investigación científica son libres» ${ }^{2}$. El art. 15.3 del Pacto Internacional de Derechos Económicos, Sociales y Culturales recoge la obligación de los Estados firmantes de garantizar «la indispensable libertad para la investigación científica y para la actividad creadora».

Nuestro texto se caracteriza por poner el acento en la acción innovadora en sí misma, con independencia de su naturaleza artística o científica. Además, incluye explícitamente las facultades de producción y creación, configurando un nuevo tipo de discurso público específicamente protegido que se suma a las libertades de expresión e información.

Esta claridad constitucional contrasta con el escaso desarrollo doctrinal y jurisprudencial del precepto; la razón está seguramente en el efecto expansivo de la concepción de la libertad de expresión como principio genérico de libre difusión de todo tipo de contenidos, al modo del free speech estadounidense, ignorando que en el modelo español sólo se protegen tres o cuatro discursos específicos. Esa perspectiva pone el acento en los «límites» externos que se pueden imponer al ejercicio del derecho, entendido como mero mandato de optimización, antes que en la estricta delimitación previa de cuáles son los mensajes constitucionalmente protegidos. Ello ha contribuido a la indefinición en torno al contenido esencial de cada una de las categorías de discurso protegido.

\section{LA SINGULARIDAD DE LA CREACIÓN COMO DISCURSO PROTEGIDO}

El derecho a explorar libremente líneas de investigación o de creación imaginativa está sometido casi exclusivamente a estrictas consideraciones de orden público $^{3}$ y goza de la protección que proporciona la prohibición de censura, entendida como interdicción de interferir en la plena libertad creativa. Más complicada es la cuestión de su libre difusión.

Constitución Italiana declara que el arte y la ciencia son libres y lo conecta con la enseñanza. También aparece en las constituciones de Croacia, Polonia y Grecia, entre otras.

2 Sobre este artículo, vid. Verbruggen, V., «Liberté des arts et des sciences», O. De SchutTer (coord.) Commentary of the charter of fundamental rights of the European Union, 2006, pp. 132-140, que distingue las libertades de investigación, académica y artística aunque a todas les impone los mismos límites que a la libertad de expresión. Este derecho ha sido invocado en la STJUE de 29 de julio de 2019, en el asunto Pelham Gmb y otros (C-476/17), en materia de derechos de autor, para señalar que el sampling, que es la técnica que crea obras sonoras a partir de fonogramas extraídos de obras existentes de otros autores «constituye una forma de expresión artística comprendida en la libertad de las artes». Considera, además, que es un derecho que forma parte de la libertad de expresión.

3 Así, la STC 81/2020, de 15 de julio, aborda en su FJ 16 el caso de la prohibición de maltrato animal en la elaboración de obras audiovisuales. Se trata de una disposición de orden público que no afecta a la esencia de la libertad de creación. 
En el ámbito de la libertad de expresión, nuestra Constitución no protege genéricamente la acción de comunicar, sino sólo la difusión de contenidos concretos especificados en su texto. Entre ellos el art. 20.1.b) incluye a los que, sin ser hechos veraces ni pronunciamientos ideológicos sobre el devenir social, tengan un valor espiritual determinado, conectado con su sentido innovador.

Ciertamente, la relación entre los diversos derechos de la comunicación englobados en el mismo artículo no ha sido nunca bien resuelta por el Tribunal Constitucional. Le costó separar los distintos discursos del reconocimiento de la libertad de expresión entendida como derecho a la difusión de juicios de valor con relevancia pública, que tomó inicialmente como el derecho «madre» del que emanaban todos los demás ${ }^{4}$. En los años ochenta, a raíz del conflicto de competencias respecto a un Decreto catalán sobre la calificación de espectáculos teatrales y artísticos, interpretó la libertad de creación como una manifestación más de la libertad de expresión. En efecto, el derecho a la producción y creación literaria, artística, científica y técnica, reconocido y protegido en el apartado b) del mencionado precepto constitucional, no es sino una concreción del derecho — también reconocido y protegido en el apartado a) del mismo- a expresar y difundir libremente pensamientos, ideas y opiniones, difusión que referida a las obras teatrales presupone no sólo la publicación impresa del texto literario, sino también la representación pública de la obra, que se escribe siempre para ser representada» ${ }^{5}$.

Esta idea de que la Constitución garantiza tanto unos derechos genéricos como algunas de sus concreciones prácticas resultaba del todo ajena al concepto de derecho fundamental como garantía de un espacio determinado de libertad para el desarrollo de la personalidad. Implica aceptar que nuestra ley fundamental incluye bajo la fórmula «libertad de expresión» una mera declaración de principios cuyo valor jurídico dista mucho del de los auténticos derechos de la personalidad. Con este principio orientativo convivirían algunas de sus manifestaciones concretas que gozarían —ellas sí- de eficacia directa. Así, al hablar de un difuso derecho a comunicar cualquier contenido se priva al derecho de eficacia directa y se deja su aplicación al albur de la voluntad de los operadores jurídicos.

Frente a esta pérdida de la eficacia jurídica de la Constitución, resulta necesaria una interpretación que dote de contenido vinculante a cada derecho constitucional, sin perjuicio de su carácter adicional como valor del ordenamiento. De

4 Hay que señalar que gran parte de la doctrina se siente cómoda con esta concepción. Así Diez-PICAzo, L.M., Sistema de derecbos fundamentales, Civitas, 2005, p. 345, cree que la libertad del arte y de la ciencia forma parte del mundo de la libertad de expresión e información. Por su lado, Martín-Retortillo Baquer, L., «Respeto a los sentimientos religiosos y libertad de expresión», Anales de la Real Academia de Jurisprudencia y Legislación, 2006, p. 597, entiende que la libertad de libertad de expresión artística es un derivado natural de la libertad de expresión.

5 STC 153/1985, de 7 de noviembre. 
hecho, de la lectura comprehensiva del texto del art. 20 CE se deduce sin lugar a dudas que en el ámbito de la comunicación el constituyente optó por identificar cuáles son los discursos protegidos, agrupando cada uno de ellos bajo un derecho específico ${ }^{6}$.

Así parece haberlo visto posteriormente el Tribunal Constitucional a partir, sobre todo, de la diferenciación radical entre la libertad de expresión, referida a la difusión ideas relevantes y la libertad de información que se centra en la transmisión de hechos veraces. En esa línea, en la sentencia mencionada ya existía un voto particular en el que el magistrado Rubio Llorente señala: «a mi juicio, ni la libertad de producción y creación literaria, artística, etc., es una concreción del derecho a expresar y difundir libremente el pensamiento, sino un derecho autónomo, ni la protección de la juventud y de la infancia es una función reservada en exclusividad al Estado». Con el tiempo, esta posición se hizo mayoritaria, dando por fin lugar — con algún que otro sobresalto ${ }^{7}$ - a la firme declaración de que la inclusión en la Constitución de la libertad de creación «le otorga la consideración de derecho autónomo, con un ámbito propio de protección» ${ }^{8}$.

De este modo, la difusión de contenidos innovadores que implican una reflexión creativa se suma a la protección que otros apartados del artículo $20 \mathrm{CE}$ otorga a los mensajes que aportan una reflexión política o social y a los que contienen hechos contrastados y públicamente relevantes. El valor constitucional de las obras artísticas y científicas tiene, pues, el mismo nivel que el de los hechos y los mensajes políticos.

Aún así, en razón de la naturaleza de su objeto, los distintos contenidos creativos previstos en la Constitución funcionan de manera jurídicamente distinta: la difusión del conocimiento se refiere a la innovación basada en el análisis metódico de hechos de la realidad; el arte está relacionado con la plasmación de visiones del mundo en un formato estético determinado.

\section{CREACIÓN ARTÍ́STICA Y FICCIÓN}

La libertad de creación científica está orientada al avance de la sociedad mediante el análisis crítico de hechos singularizados. Se sostiene en el equilibrio entre la permanente necesidad de debate sobre la interpretación los hechos y las exigencias formales en ese proceso derivadas de la aplicación del método

6 Cfr. Urías, J., «La libertad de creación. Art. 20.1.b)», RodríGuez-Piñero, M. y Casas, M. E. (Dir.) Comentarios a la Constitución española, Madrid, BOE, 2018, p. 619.

7 Así, en la STC 81/2020, de 15 de julio, FJ 16, parece volverse al criterio de los primeros años ochenta cuando se dice que la libertad de creación «es una concreción del derecho fundamental a la libertad de expresión, si bien con un ámbito de protección propio».

8 STC 34/2010, de 19 de julio 
científico ${ }^{9}$. Suscita toda una problemática que no se tratará en el presente estudio, centrado exclusivamente en la cuestión de la creación artística.

El arte, en cierto sentido, representa lo contrario de la ciencia: si ésta busca una explicación experimental del mundo guiada por la neutralidad y el estudio de los datos, aquél lo hace mediante la construcción de mundos propios, autónomos de la realidad. Tienen en común el elemento creativo y se unifican constitucionalmente a partir del concepto de cultura y su relevancia democrática ${ }^{10}$. El principal problema ontológico del arte es la imposibilidad de encontrar una definición suficientemente operativa y omnicomprensiva de todas sus posibles manifestaciones ${ }^{11}$. La esencia misma del arte, poner en duda el mundo establecido, y su constante innovación transgresora impiden que exista tal definición ideal $^{12}$ : en el momento en que se define el arte surge la posibilidad inevitable de experimentar artísticamente contraviniendo esa definición. Así, lo que caracteriza a la expresión artística no es tanto un resultado abarcable y definible $a$ priori como la voluntad artística. El «método artístico» consiste en la reflexión propia del autor que se lanza a crear una obra con la pretensión de que sea arte $^{13}$. Esa aspiración sólo está adecuadamente dirigida, alcanzando consideración artística, cuando transforma la realidad vivida a través de la estética, logrando un nivel de generalidad y ejemplaridad que trasciende a la experiencia individual.

Desde el punto de vista constitucional no es necesario establecer una definición valorativa y definitiva de lo artístico, pues se trata tan sólo de proteger los valores intrínsecos a un modelo de discurso. Jurídicamente, lo relevante es el método, excluyendo cualquier valoración sobre la calidad los resultados. Y ese método supone compaginar un elemento reflexivo sobre la existencia y trascendental, con un formato innovador que establezca un diálogo con los cánones

9 Cfr. sobre todo la STC 43/2004, de 23 de marzo. Vid. Robles Latorre, P., «Hechos, opiniones e historia (Comentario a la STC 43/2004, de 23 de marzo)», Derecho Privado y Constitución, n. ${ }^{\circ}$ 19, 2005, pp. 319-338.

10 En este sentido, la idea de P. HÄBERLE de que «la libertad se convierte en libertad 'plena' a través de la cultura», «La protección constitucional y universal de los bienes culturales: un análisis comparativo», REDC n. ${ }^{\circ} 54,1998$, p. 28.

11 Sobre la dificultad de definir el arte incluso desde el terreno de la estética y la filosofía, vid. VÁzQUEZ Alonso, V.J. «La libertad de expresión artística. Una primera aproximación», Estudios de Deusto, n. ${ }^{\circ} 62$, 2014, que parte de la noción de emoción estética.

12 García Rubio, M.P., García Rubio, M.P., «Arte, religión y Derechos Fundamentales. La libertad de expresión artística ante la religión y los sentimientos religiosos (algunos apuntes al hilo del caso Javier Krahe)», Anuario de derecho civil, n. ${ }^{\circ}$ 67, 2014, p. 418.

13 La doctrina estadounidense, vincula el arte con la búsqueda de la verdad, el control del poder y la autorrealización del artista. Cfr. Por todos, Eberle, E.J., "Art as Speech», University of Pennsylvania Journal of Law E Social Change, n. ${ }^{\circ} 11,2008$, pp. 1-2. Es producto de un sistema en el que la libertad artística no tiene entidad positiva en el texto constitucional, de modo que se pretende identificar en el arte los valores tradicionales de la libertad de expresión. Por eso resultan inútiles en sistemas, como el nuestro, que se basan en la noción de «bien protegido» intrínseco a cada derecho específicamente reconocido en la Constitución. 
habituales de la sociedad ${ }^{14}$. Lo artístico sintetiza categorías existenciales a través de la imaginación personal. Jurídicamente, el aspecto relativo a la divulgación de la obra artística se desvincula del derecho individual al desarrollo de la personalidad del creador y se pone en relación con esta trascendencia social de la obra.

Sólo a partir de esta reflexión es posible una aproximación jurídica al arte constitucionalmente protegido. Para su comprensión es especialmente ilustrativo entender la problemática que han enfrentado en este terreno los ordenamientos de nuestro entorno, entre los que destaca el francés, pero también Alemania o, desde otra perspectiva, la jurisprudencia del Tribunal Europeo de Derechos Humanos.

\section{La construcción de la excepción artística y su aplicación en Francia}

En el mundo jurídico francés lo artístico supone una idea personal encarnada en una forma original, siendo ambos aspectos prácticamente inescindibles. Jurídicamente, renunciando a apreciar el mérito o el valor de la obra, el objeto protegido es esa creación que combina idea y forma en la medida en que con ello ofrece una reflexión original sobre el mundo ${ }^{15}$. La 'excepción de ficción' siempre ha estado de un modo u otro presente en la jurisprudencia gala, referida sobre todo a la obra literaria. Sirvió, por ejemplo, en 1897 para desestimar la demanda de un ciudadano que se había visto reconocido en un personaje de la novela Cara a la bandera, de Julio Verne ${ }^{16}$.

En general, para excluir la responsabilidad de un autor por el contenido de su obra se exige, de una parte, demostrar el carácter ficticio del discurso y de otra que el autor mantenga una 'distancia narrativa' suficiente respecto a su contenido ${ }^{17}$. Esos dos elementos son esenciales para excluir pretendidos daños a otros bienes protegidos.

Respecto al primer punto, la noción de ficción suscita —en cualquier ordenamiento - cuestiones relevantes derivadas de la intensa imbricación entre imaginación y realidad. La ficción supone el reconocimiento de la autonomía de la obra: una novela no expresa el discurso propio del autor, pues si lo hiciera, dejaría de ser novela. Tal autonomía permite al artista expresarse sobre todos los temas, incluidos asuntos políticos o morales, sin temor a sanciones estatales.

14 Sobre ello, vid. Díez Bueso, L., Los Límites de la Creación Artística en Estados Unidos y Europa, Valencia, Tirant Lo Blanch, 2017, pp. 89 y s.

15 Vid. Tricoire, A., Petit traité de la liberté de création, La découverte, Paris, 201, p. 111.

16 Cfr. Dalloz, Jurisprudence générale, 1897, p. 112.

17 Vid. Arzoumarov, A., «La fiction objet de droit ? Réflexions sur une catégorie juridique émergente en droit de la presse», en Ch. BARON y L. Ellena (Ed), «La fiction éclaire-t-elle les savoirs ?», revue «a licorne», 2018. 
De ese modo, para poder valorar la ficción previamente hay que distinguir entre lo verdadero y lo inventado o falso.

Como punto de partida, la obra ha de ser juzgada en su integridad. Su carácter artístico o no sólo se aprecia mediante el reconocimiento del trabajo como un todo. Adicionalmente es necesario tomar en consideración la multiplicidad de interpretaciones, a partir del principio de que la ficción es no literal ${ }^{18}$. El contexto de la obra permite identificar la ficción en esa dialéctica entre realidad e imaginación.

La ficción crea una ilusión referencial ${ }^{19}$ que dura mientras se lee el libro, se ve la película o se escucha la canción, pero que desparece cuando el espectador vuelve al mundo real. Si ese retorno no se produce puede deberse a una falta de imaginación del lector o a que el autor, deliberadamente, no ha construido una obra que pueda calificarse de ficción. En este sentido, la libertad de creación artística tiene también carácter institucional pues el desarrollo de la educación artística en la sociedad resulta esencial para discernir entre lo creativo y lo puramente descriptivo.

Con todos estos elementos se puede llegar a identificar la ficción y se entra en el ámbito de la libertad de creación protegida. Ello no conlleva, no obstante, en todo caso que el discurso sea inane jurídicamente. Históricamente los efectos subversivos de la ficción y su modo de representación del orden social demuestran que su autonomía no puede entenderse como un absoluto por parte del Estado. La distinción entre autor, narrador y personajes (o la que hay entre apología y representación) debe ser tenida en cuenta para identificar la ficción pero se da toda una pluralidad de situaciones mixtas que no excluye de manera absoluta los efectos sociales de las obras artísticas ${ }^{20}$ pues implica la posibilidad de que se afecte a otros bienes que merecen protección.

En este punto, el ejemplo que mejor resume la jurisprudencia francesa es sin dudad la novela Pogrom, de Eric Bénier-Burckel, publicada en 2005. En ella, un personaje fuertemente antisemita reitera expresiones que incitan al odio contra los judíos. El autor fue acusado por el ministerio fiscal de un delito de injurias antisemitas, de otro de provocación al odio racial y de otro de difusión de mensaje pornográfico susceptible de llegar a un menor. Al respecto, la Sala diecisiete del Tribunal Correccional de Paris, competente en los asuntos de prensa, señala que «la creación artística necesita de una mayor libertad de expresión del autor, que puede expresarse tanto sobre los temas consensuales como sobre cuestiones que molestan, chocan o inquietan». Ello implica la legitimidad de incluir personajes

18 Vid. el clásico trabajo, SEARle, J.R. «Le statut logique du discours de la fiction», Sens et expression, Minuit, Paris, 1982, pp. 101-120; también, F. de CHALONGE, «Le langage et la fiction : la description linguistique de la fiction littéraire», en Usages et théories de la fuction: Le débat contemporain à l'épreuve des textes anciens (XVIe-XVIIIe siècles), Presses universitaires de Rennes, Rennes 2004, pp. 17-37.

19 Cfr. Schaeffer, J.-M., Pourquoi la fiction?, Seuil, Paris, 1999, p. 263.

20 Cfr. Sapiro, G., «Politique de la fiction et fictionnalisation du politique face aux limites de la liberté d'expression», Raison-publique.fr, 4 mayo 2014. 
que cometen delitos, sin incluir un rechazo explícito a ello ${ }^{21}$. Además en estos asuntos el tribunal competente no puede actuar como juez del valor literario de la obra sino sólo de la naturaleza y extensión de las expresiones dañinas que incluya ${ }^{22}$.

En el caso, los mensajes violentos o pornográficos denunciados son comportamientos que se le atribuyen a un personaje de la novela en el desarrollo de una escena de zoofilia y sodomía expuesta en términos particularmente crudos. Sobre ello el tribunal entiende que «la noción misma de obra de ficción implica la existencia de una distancia, que puede ser irreductible, entre el propio autor y las intenciones o acciones de sus personajes; dicha distancia, apreciada bajo el prisma deformante de la ficción, puede conllevar la desaparición del elemento material de los delitos imputados». La imputación de apología se diluye en el abierto mundo de la ficción ${ }^{23}$. Los pasajes discutidos no pueden ser entendidos como incitaciones o injurias en razón de la naturaleza novelesca de la obra en la que se integran. En ese contexto, el autor se ha abstenido además de cualquier enfoque apologético en la realización de su proyecto de descripción y exploración de las formas del mal.

Parte de la doctrina considera errónea la idea de que el autor no se expresa jamás a través de un relato de ficción. Cree que sería más acertado indagar en los enunciados y el contexto de las afirmaciones enjuiciadas en cada caso para discernir si el autor las asume como propia. La asunción de que todo en una novela es realidad inventada supondría declarar la impunidad total de la ficción, abriendo la puerta a abusos por parte de autores que presentan así sus ataques a la sociedad ${ }^{24}$.

Para evitarlo, uno de los criterios que usa la jurisprudencia francesa para discernir entre ficción y dicción es la identificabilidad de los aludidos. No hay daños a la persona si ésta no aparece identificable en la obra objeto de litigio. La identificación más obvia se produce cuando se usa el nombre propio de los aludidos, que son personas existentes: abre la puerta a la posibilidad de difamaciones o a invasiones de su vida privada, aunque no las conlleva de manera necesaria. En el caso - sobre todo - de personas famosas es posible que, pese al uso de un nombre ficticio, la atribución de hechos al personaje permita identificar imputaciones a una persona existente.

Esta asunción lleva en ocasiones a los tribunales franceses a ordenar que se cambien nombres propios que aparezcan en obras artísticas atribuyéndoles características negativas, para hacer imposible su identificación con personas existentes. Es ilustrativo el caso del libro «Las partículas elementales» de Michel Houllebeq. En la obra se mencionaba un camping, situado cerca de la ciudad de

21 Sentencia de la 17. Sala del Tribunal de Gran Instancia de París, de 16 de noviembre de 2006.

22 Vid. Tricoire, A.,. «Quelques considérations générales et deux applications pratiques pour cerner juridiquement la notion de fiction», La liberté de création littéraire et l'exception de fuction, en Le MOTif - Observatoire de la liberté de création, octubre 2009.

23 Cfr. Tricoire, loc. cit.

24 Cfr. Arzoumarov, «La fiction ... cit., 2018 
Royan y llamado «El espacio de los posible», que se presenta como un lugar de depravación. Como quiera que existía un camping con tal nombre y en ese mismo lugar, judicialmente se impuso al autor cambiar el nombre y la localización para evitar atribuciones erróneas, como un modo de evitar que la ficción se asuma como realidad ${ }^{25}$.

La identificabilidad del afectado viene determinada por la posibilidad de confusión por parte del lector. Se aprecia, por ejemplo, cuando el nombre usado no es muy común en determinada zona, o cuando hay detalles de similitud entre el personaje y la persona real que permitan prever que parte del público pueda llegar a identificarlos ${ }^{26}$. No se da, en cambio, cuando la coincidencia es meramente fortuita, de modo que no se pueda establecer ninguna relación entre el autor y la persona que se queja de haber sido mencionada en una obra de ficción.

Un ejemplo del uso de este criterio puede verse en el asunto contra el libro «Le procès de Jean-Marie Le Pen», escrito por M. Lindon. Narra el ficticio proceso judicial contra un militante del Frente Nacional que una noche, mientras pegaba carteles del partido por las calles de París asesina a un joven árabe únicamente en razón de sus orígenes. Cuando es acusado, su abogado desvía las acusaciones hacía el presidente del partido, Jean-Marie Le Pen, este sí una persona verdaderamente existente. Cuando éste se querella, el Tribunal

Inicialmente competente señala que, si bien el autor ha escogido escribir una novela, pone en escena a personajes reales con la intención de acusar directamente al político. Así, «aunque se trata de una novela y las palabras juzgadas solo son pronunciadas por personajes ficticios, esta obra, sin embargo, tiene como fin exponer unas ideas claramente explícitas y transmitir cierta imagen de Jean-Marie Le Pen, de su partido y de su comportamiento». El autor no solo ha creado una obra de ficción; ha presentado a sus lectores a Jean-Marie Le Pen en sus actividades cotidianas de presidente del Frente Nacional y ha querido criticarlo, al igual que a su partido, y confrontar sus ideas ${ }^{27}$. Las situaciones son tan cercanas a acontecimientos reales que pueden llevar al lector a no distinguir claramente entre la realidad y la ficción. En estas circunstancias se aplica el criterio habitual de la libertad de expresión y, tratándose de imputaciones no veraces, se condena al escritor. Al desestimar el recurso contra esta decisión, el Tribunal de Apelación ${ }^{28}$ destaca algunas de las expresiones difamatorias. Así, una larga declaración del abogado protagonista calificando al señor Le Pen de «vampiro que se alimenta del resquemor de sus electores, y a veces también de su sangre, como de la sangre de

25 Sentencia de la Sala 17. a del Tribunal de Gran Instancia de París de 4 de septiembre de 1998.

26 Cfr. Arzoumarov, A., «Toute ressemblance avec...' Quand le droit se penche sur l'usage fictionnel du nom propre», N. Laurent y Ch. Reggiani (Ed.), Les Seuils du nom propre. Limoges:Lambert Lucas, 2017.

27 Vid. Arzoumarov, A., «L'auteur peut-il être tenu responsable des propos fictifs de ses personnages? Retour sur le feuilleton judiciaire Lindon/POL vs Jean-Marie Le Pen», K. Germoni, C. Stolz (Ed.) Aux marges des discours rapportés: Formes louches et atypiques en synchronie et en diachronie, Paris: Academia, 2019

28 Sentencia del Tribunal de Apelación de Paris, de 13 de septiembre de 2000. 
sus enemigos». En las pocas páginas del libro que siguen a estas afirmaciones no hay nada que introduzca cierta distancia del narrador con su contenido. Igual sucede con la afirmación de que no es el presidente de un partido sino el jefe de una banda de asesinos, que el autor pone en boca de unos manifestantes pero de la que nunca se distancia ${ }^{29}$.

La debilidad de la línea divisoria entre ficción artística y realidad en los casos en los que una persona es reconocible se pone de manifiesto a propósito de otras disciplinas artísticas: un artista gráfico tomó una serie de fotografías íntimas a su pareja partir de las cuales elaboró con bolígrafo una serie de obras de técnica hiperrealista. Tras su separación, la mujer presenta una demanda instando a que cese la difusión de los cuadros, alegando que suponen una lesión de su derecho a la imagen y a la vida privada. El Tribunal falla que, puesto que se reconoce a la persona y no media su consentimiento para la difusión, se lesionan de sus derechos a la intimidad y la propia imagen ${ }^{30}$. La decisión suscita bastantes dudas en la medida en que las obras realizadas con bolígrafo tienen entidad artística propia frente a la mera representación fotográfica de la persona.

La intimidad plantea problemas específicos en la medida en que cuando se crean obras artísticas a partir de personas o instituciones reales, el valor exculpatorio de la libertad artística está en relación directa con la posibilidad de diferenciar entre realidad y ficción. Así, el asunto relativo al libro L'enfant d'Octobre de $\mathrm{Ph}$. Besson, protagonizado por dos personas reales - los esposos Villemin-, que en un caso con enorme repercusión pública fueron acusados y absueltos de la muerte violenta de su hijo Gregory. En la obra se intercalan datos y hechos reales con reflexiones interiores del narrador y una reconstrucción novelesca del crimen inventada por el autor. Los señores Villemin lo demandaron por atentado contra la vida privada, consiguiendo que fuera condenado.

El Tribunal entiende que «el carácter en parte novelesco de un escrito no puede permitir al autor que utilice para su inspiración, sin acuerdo de los protagonistas, elementos de su vida privada; intromisiones en la intimidad de personas aun con vida, que responden a las exigencias artísticas queridas por el autor, no pueden venir justificados, incluso aunque los acontecimientos vividos susciten el legítimo interés del público, por el derecho a la información o a contribuir a un debate de ideas» ${ }^{31}$. En definitiva, de deduce que el autor no ha sido capaz de presentar los hechos con la suficiente distancia como para que el lector entendiera que eran fruto exclusivo de su imaginación y no extraídos de la vida privada de las personas mencionadas ${ }^{32}$.

29 Este asunto dará lugar a la STEDH en el asunto Lindon, Otchakovsky-Laurens y July c. Francia, de 22 de octubre de 2007, citada más adelante.

30 Orden cautelar del Tribunal de Gran Instancia de París de 10 de enero de 2013.

31 Sentencia del Tribunal Correccional de París, de 17 de septiembre de 2007.

32 Cfr. Tricoire, A., «Quelques considérations...», cit. 
Esta doctrina parece no aplicarse del mismo modo en los casos de autoficción, género muy en boga en el Hexágono ${ }^{33}$, en el que el autor crea obras de indudable naturaleza artística a partir de la narración de su propia realidad. En 2003 se rechazó la demanda del exmarido de la escritora Camille Laurens que aparecía mencionado en su novela L'Amour, roman; el Tribunal, tras constatar que no hay afectación de relevancia a la vida privada señala que «el único motivo alegado en definitiva — que se habían conservado los nombres reales de su familia - no basta para privar a esta obra del carácter ficticio que confiere a toda obra de arte su dimensión estética, ciertamente inspirada por necesidad en lo vivido por el autor, pero igualmente pasado por el prisma deformante de la memoria y, en materia literaria, de la escritura» ${ }^{34}$. En 2006 corre la misma suerte la denuncia de la actriz que denunció al cineasta Arnaud Desplechin por haberse inspirado en acontecimientos de su vida para la película Rois et reine.

Más recientemente, vuelve a suceder en un asunto contra el escritor Nicolas Fargues, demandado por su exmujer que se reconocía en la novela J'étais derrière toi, en la que se narraba una separación violenta. Le reprochaba haber sacado a la luz detalles de su vida íntima, párrafos de correspondencia privada y hasta diarios personales. La sentencia reconoce la gran proximidad entre el argumento y los hechos realmente sucedidos en la vida de la pareja, pero toma en cuenta que solo un círculo íntimo de conocidos podía establecer tal relación. Además señalaba que «la libertad de creación debe ser considerada como la forma más desarrollada de la libertad de expresión en un régimen democrático»., concluyendo que «el género de la autoficción debe, so pena de desaparecer, poder practicarse con el máximo de seguridad jurídica y no debería verse restringido o incluso anulado por una protección demasiado rigurosa de la vida privada de las personas implicadas» ${ }^{35}$

Un examen detallado de todos estos casos pone de manifiesto que las supuestas lesiones de la vida privada que se alegan tenían carácter leve y se trataba de obras con un importante componente creativo. Sin embargo, si se tratase de una mera reproducción de la realidad deberías ser de aplicación los mismos criterios de enjuiciamiento que a cualquier otra publicación, notablemente la prensa. Así se evidencia en el asunto de la novela Les Petits, de Ch. Angot, escritora conocida por dedicarse a la autoficción, que narra las intimidades vitales de una mujer, madre de cinco hijos — cuatro de ellos mulatos-y de su relación con los hombres. La mujer aparece identificada con el nombre de Heléne, pero la autora resulta demandada por Élise, antigua pareja de su novio, que se ve identificada en todos los detalles del libro, al que considera un ataque contra su vida privada.

33 Vid., por ejemplo, Jeannelle, J.-,L., «Le procès de l'autofiction», Études, 2013/9, vol. 419, pp. 221-230.

34 Sobre el tema, vid. Heinich, N., «Les limites de la fiction», L'Homme, n. ${ }^{\circ}$ 175/176, Vérités de la fiction, 2005, pp. 57-76

35 Sentencia de la Sala 17. ${ }^{a}$ del Tribunal de Gran Instancia de París de 16 de mayo de 2012. 
El Tribunal le da la razón a la demandante ${ }^{36}$. Entiende que las conexiones de los personajes del libro con la realidad de la vida de la demandante son particularmente fuertes, estrechos e insistentes. A su juicio, los personajes de la obra están lejos de ser «seres de papel» en la fórmula de Paul Valéry; en el libro la realidad de la vida de la demandante aparece reproducida tanto en los detalles banales como en sus aspectos más íntimos, lo que hace «desaparecer en la mente del lector cualquier duda sobre el enraizamiento del relato en la realidad», por lo que la novela deja de ser «expresión de una verdad universal que afecta a la condición humana». En ausencia de auténtica ficción, las ofensas a Élise son especialmente perjudiciales porque se usan para presentarla como una persona manipuladora de un modo que no puede separarse del interés personal de la autora, implicada en una relación sentimental con el antiguo compañero de la demandante.

Así pues, por encima de los géneros, resulta necesario analizar caso por caso si la actividad creativa del autor es o no capaz de transformar a través de la estética la realidad vivida. de tal modo que alcance un nivel de generalidad y ejemplaridad que trascienda a la experiencia individual ${ }^{37}$. Si la obra procede esencialmente a reiterar la realidad tal cual es o a mostrar la opinión propia del autor sobre ella, se está en el terreno de la dicción que debe juzgarse con los mismos criterios aplicables a la libertad de prensa.

Por último, hay que señalar también las modulaciones derivadas del estilo propio de cada género artístico. En 2009, a raíz de un concierto, se suceden una serie de demandas por parte de asociaciones contra el cantante de rap conocido como Orelsan, acusándole de promover la violencia contra las mujeres en sus canciones. Tras una condena en primera instancia y una serie de vicisitudes procesales el asunto es resuelto definitivamente por un Tribunal de Apelaciones que declara que «el terreno de la creación artística, por ser fruto del imaginario propio del creador, está sometido a un régimen de libertad reforzada a fin de no otorgar al juez un poder de censura que se ejercería en nombre de una moral necesariamente subjetiva para prohibir modos de expresión, a menudo minoritarios, pero que son también el reflejo de una sociedad viva y que tienen su lugar en una democracia ${ }^{38}$. Este régimen debe tomar especialmente en cuenta el estilo de la creación artística de la que se trate. El rap puede ser percibido por algunos como un modo de expresión de naturaleza brutal, provocadora, vulgar e incluso violenta, ya que se presenta como reflejo de una generación abusada y que ha terminado por estallar. A partir de esa consideración, le corresponde al Tribunal inquirir si más allá de expresiones impugnadas, formuladas en el estilo por definición agresivo del rap, el autor ha querido de una parte injuriar a las mujeres en razón de su sexo, y de otra provocar a la violencia, al odio o a la discriminación

36 Sentencia de la 17. ${ }^{a}$ Cámara del Tribunal de Gran Instancia de Paris de 27 de mayo de 2013.

37 Cfr. SAPIRO, G., «Droits et devoirs de la fiction littéraire en régime démocratique : du réalisme à l'autofiction», Revue critique de fixxion française contemporaine, 2012.

38 Sentencia del Tribunal de Apelación de Versalles de 18 de febrero de 2016. 
contra ellas, o si sus canciones expresan, en el estilo musical que le es propio, el malestar de una parte de su generación. En el caso concreto, los textos de las canciones muestran a personajes que han sufrido abusos y viven en situación de fracaso vital; a una juventud desencantada, incomprendida por los adultos, que vive su porvenir entre la angustia y la frustración. El cantante no reivindica personalmente la legitimidad de los actos violentos, provocadores o sexistas de sus personajes. Inventa criaturas que reflejan esa situación de desesperación, pero lo hace desde cierta distancia con ellas. "Atentaría gravemente contra la libertad de creación el querer prohibir estas formas de expresión. Las palabras de sus textos en discusión, que son por naturaleza injuriosas y violentas respecto a las mujeres si se toman de manera aislada (...), deben ser en realidad analizadas en el contexto de la corriente musical en la que se inscriben y tomando en cuenta los personajes imaginarios, abusados y sin control, que las expresan. Sancionarlas como injurias públicas por razón de sexo o como provocación a la violencia, al odio y a la discriminación hacia las mujeres, conllevaría censurar toda forma de creación artística inspirada en el malestar, el desarraigo y el sentimiento de abandono de una generación, violando el principio de la libertad de expresión» ${ }^{39}$.

\section{Breve excurso sobre Alemania: el ejemplo del asunto Esra}

El valor de la ficción a la hora de configurar el derecho a la difusión artística como derecho fundamental autónomo, con perfiles propios, ha sido tomado en cuenta prácticamente en todos los ordenamientos jurídicos de nuestro entorno. En Alemania, la Ley Fundamental reconoce expresamente la libertad de creación artística en su art. 5. III. La virtualidad de esta declaración ha estado siempre en discusión, y hasta hace poco la doctrina constitucional existente al respecto descansaba esencialmente en la de la sentencia del Tribunal Constitucional en el asunto Mephisto ${ }^{40}$. En aquella ocasión, se trataba de la publicación de una novela de 1936 de T. Mann en la que narraba la triunfante carrera de un actor advenedizo que durante el tercer Reich renuncia a todos sus principios y pacta constantemente con el poder. Aunque el personaje aparecía con otro nombre, era claramente reconocible como un actor realmente existente, cuyo heredero reclamó y obtuvo la prohibición de la obra. El Tribunal Constitucional no fue capaz de llegar a un acuerdo por la situación de empate entre sus miembros, así que la decisión de los tribunales inferiores nunca fue anulada.

Sin embargo, la sentencia hacía importantes consideraciones sobre la libertad artística y sus límites, que han tenido un profundo eco en la doctrina germánica:

39 Vid. Englebert, J., «L'œuvre artistique, 'miroir effrayant' de la société — À propos de la relaxe justifiée du rappeur Orelsan», Légipresse n. ${ }^{\circ} 337$, Abril 2016, pp. 226-231.

40 BVerfGE 30, 173, de 24 de febrero de 1971. 
«toda actividad artística es un entrelazamiento de procesos conscientes e inconscientes, que no se pueden resolver racionalmente. La intuición, la imaginación y el sentido artístico operan juntos en la creación artística». No es un mero acto de comunicación, sino la expresión más directa de la personalidad individual del artista. Eso es válido incluso aceptando que el arte se basa en las impresiones, experiencias y vivencias del artista extraídas de la vida real, pero expresadas a través de una forma particular de lenguaje. La protección de la libertad artística garantiza tanto la libertad en el espacio de trabajo creativo como la difusión efectiva de la creación artística. Aunque el arte no pueda ser definido jurídicamente, se encuentra protegido sin reserva alguna por el Art. 5, párrafo 3 de la Ley Fundamental.

Si se trata aquí la situación alemana no es por esta doctrina, sino por cómo se adapta en un caso especialmente ilustrativo que aborda la cuestión de la autoficción. La novela Ezra, de M. Biller narra la historia romántica entre un escritor y una actriz. Él es judío y ella turca; la obra se centra en los problemas de la pareja derivados en de las diferencias culturales y azuzados por la agresiva interferencia de la madre de ella. Tras su publicación, la actriz A. Romey, que había sido pareja del escritor, y su madre presentaron una demanda señalando que había plena coincidencia entre sus personas y los personajes protagonistas de la novela. Le atribuían el sacar a la luz pública determinados detalles de su vida privada sin contar con su consentimiento. En consecuencia, determinadas páginas de la obra fueron prohibidas por el Tribunal Supremo Federal.

El editor acudió entonces al Tribunal Constitucional, que en una ajustada decisión denegó su amparo. En la sentencia concluye que a pesar de la declaración del autor de que se trataba de una obra de ficción, el libro estaba basado en su vida real. El círculo cercano a la recurrente podía identificarla fácilmente como la protagonista y conocer así detalles íntimos de su vida amorosa. El Tribunal reconoce que «la libertad artística incluye el derecho a usar modelos inspirados en la realidad de la vida». Así, parte de que hay una presunción de que toda obra es ficción, siempre que su autor no la presente como una relación de hechos reales. Esto, sin embargo, puede resultar desvirtuado cuando del análisis global de la obra se deduzca que lleva a que los lectores entiendan las descripciones que contiene como referidas al mundo de la realidad. «Existe una correlación entre la medida en que el autor crea una realidad estética separada de la realidad y la intensidad de la afección de los derechos de la personalidad. Cuanto más fuertes son el uso de la imagen y más arquetípica es la imagen, más grave es el deterioro del derecho de la personalidad. Cuanto más se relaciona la representación artística con dimensiones particularmente protegidas de los derechos de la personalidad, más fuerte debe ser la ficcionalización para descartar una violación de los derechos personales».

Aplicando estos criterios, concluye que respecto al personaje de la madre no se desvirtúa el carácter ficticio del personaje, por lo que no pudo haber afectación en los derechos de la personalidad de esa demandante. Las descripciones de ella incluidas en la novela se hacen desde la lejanía, sin presentarlas como experiencias propias del autor sino como meras reflexiones o reflejo de comentarios ajenos. 
Respecto a la amante descrita en la novela, sin embargo, el Tribunal Constitucional entiende que es perfectamente reconocible. La descripción de su relación íntima con el narrador, quien a su vez es reconocido fácilmente como el autor, no se presenta de un modo que resulte evidente para el lector que es mera ficción. La obra hace una «descripción exacta de los detalles más íntimos de una mujer que es claramente reconocible como la verdadera pareja íntima del autor». Aquí radica — la violación de su privacidad entendida como un aspecto de su personalidad que pertenece al núcleo de su dignidad humana. La actriz no tiene por qué aceptar que los lectores se cuestionen siquiera si los eventos sucedieron realmente.

La medida de supresión de determinados pasajes no es contraria a la libertad artística. Bien al contrario, el Tribunal Constitucional señala que no corresponde a los tribunales de justicia introducir modificaciones que alterarían la esencia de la obra, por lo que deben limitarse a prohibir las expresiones lesivas de los derechos fundamentales. Eventualmente, corresponde al autor reformular la obra de modo que excluya tales expresiones y reduzca la identificabilidad del personaje. Si en el caso concreto eso ya no es posible debido a la publicidad que ha alcanzado el asunto, no es sino un efecto de que se hayan vulnerado derechos fundamentales ${ }^{41}$.

Esta Sentencia suscitó importantes debates doctrinales en torno a la posición de la libertad de creación en el sistema constitucional y a los límites de la acción del Estado frente a ella ${ }^{42}$. De hecho, la propia decisión incluye un interesante voto particular, muy valorado desde posiciones críticas, del magistrado Hoffmann-Riem, que defiende la inmunidad de la excepción artística. En este sentido, señala que en el contexto del arte la realidad demostrable intersubjetivamente se disuelve y crea su propio nivel de interpretación y realidad. Esto se aplica a fortiori a la ficción en el sentido más estricto: es decir, a obras que se originan en la imaginación de un autor a partir de la realidad. Sólo si la intención del autor no es alcanzar un nivel de realidad estetizada, podrán tener prioridad otros derechos o bienes de la personalidad opuestos, porque entonces la obra no quedaría cubierta por el concepto constitucional del arte.

\section{Dificultades para el reconocimiento del valor artístico ante el TEDH}

El artículo $10 \mathrm{CEDH}$, a diferencia de las Constituciones de la mayoría de Estados europeos, no establece ninguna categorización entre los distintos tipos de expresión. El Tribunal Europeo de Derechos Humanos, sin embargo, sí que ha establecido algunas categorías específicas de discursos con características propias como el discurso político y el discurso publicitario. Además, el Tribunal utiliza

41 Cfr. BVerfGE 119, 1 de 13 de junio de 2007, en especial párrafos 101 y 102.

42 Por todos, vid. Von Becker, B., Fiktion und Wirklichkeit im Roman: Der Schliusselprozess um das Buch Esra. Ein Essay, Königshausen and Neumann, 2006; Bünnigmann, K., Die 'Esra'-Entscheidung als Ausgleich zwischen Persönlichkeitsschutz und Kunstfreibeit, Mohr Siebeck, Tübingen, 2013. 
una serie de herramientas que le permiten objetivar el control de la necesidad de las injerencias estatales sobre la libertad de expresión ${ }^{43}$. Entre ellas destaca la idea de que la libertad de expresión cubre «ideas que ofenden, chocan o molestan»; la necesidad de «pluralismo, tolerancia y espíritu de apertura»; o el concepto de «cuidado razonable» a la hora de recabar datos informativos. Sin embargo, no parece que ése sea el caso para el discurso artístico, ni el valor de la creación o la ficción.

Si hay una línea argumental que recorre toda la jurisprudencia relativa al art. $10 \mathrm{CEDH}$ es la protección de las ideas políticas. El Tribunal conecta fuertemente la protección de las libertades de expresión y comunicación con su función política en el Estado democrática. Eso explica que venga manteniendo una doctrina muy restrictiva respecto a las características propias de la obra artística como manifestación diferenciada y protegible de la libertad de expresión. A lo largo de su historia del TEDH, ha tenido que resolver muchísimos asuntos en los que se trataba de la imposición estatal de límites y restricciones a la difusión de obras de arte tanto literarias, como pictóricas, cinematográficas o de otro tipo. Pese a esta abundancia de ocasiones para ello nunca ha reconocido una supuesta 'excepción artística' que otorgue un ámbito más amplio de protección a la difusión de contenidos con un valor trascendente conectado con la creatividad. De hecho, bien al contrario, insiste en mostrarla como una manifestación ordinaria de la libertad de expresión. Tan es así que a menudo sólo toma en consideración el género artístico a efectos de evaluar la extensión de su difusión.

En los años ochenta el Tribunal reconoce el valor específico de la creación artística, aunque dentro de los términos propios de la libertad de expresión en el asunto Miller: «quienes crean, interpretan, difunden o exponen una obra de arte contribuyen al intercambio de ideas y de opiniones indispensable para una sociedad democrática» ${ }^{44}$. Sin embargo, esta declaración no ha llegado a tener efectos decisivos. El caso más conocido a este respecto es el asunto Otto Preminger Institut c. Austria ${ }^{45}$. Como es sabido, se trataba de una asociación que gestionaba una sala de cine y que quiso proyectar la película El Concilio del Amor del autor W. Schroeter, en la que documentaba la representación en el teatro Belli de Roma de la obra de teatro del mismo título de Oskar Panizza, autor alemán del siglo XIX. Fue prohibida por la sospecha de que incurría en un delito de denigración de preceptos religiosos. El TEDH decidió que la prohibición era adecuada en la medida en que buscaba proteger la paz religiosa en la región. En ningún momento, a lo largo de toda la decisión, se pondera o se tiene siquiera en cuenta el posible valor artístico de la obra ni su valor como ficción.

43 Cfr. Polymenopoulou, E., «Does One Swallow Make a Spring? Artistic and Literary Freedom at the European Court of Human Rights», Human Rights Law Review, Vol. 16, n. ${ }^{\circ} 3,2016$, pp. 511-539.

44 STEDH de 24 de mayo de 1988, en el asunto Müller y otros c. Suiza, (10737/84), § 33.

45 STEDH de 23 de junio de 1993, en el asunto Otto Preminger Institut c. Austria (12875/87). 
Posteriormente, en el asunto Karatas c. Turquía ${ }^{46}$, el TEDH, hace notar que el valor artístico está aún lejos de tener en sí mismo una fuerza equivalente al del valor político de una obra. El autor kurdo H. Karataş había publicado en 1991 una antología poética titulada El canto de la rebelión - Dersim. Perseguido en base a ley antiterrorista en vigor, fue condenado a un año y ocho meses de prisión por propaganda separatista y se confiscaron todos los ejemplares de la obra. El tribunal destaca que «Tomados literalmente, los poemas pueden ser considerados como que incitan a los lectores al odio, la revuelta y el uso de la violencia. Para decidir si de hecho lo hacían debe ser tomado en cuenta, sin embargo, que el medio usado por el demandante era la poesía, una forma de expresión artística que atrae sólo a una minoría de lectores». El hecho poético sólo le resulta, pues, relevante en la medida en que entiende el Tribunal que demuestra un menor daño al Estado ${ }^{47}$ derivado de lo minoritario —en su opinión- del género.

En conexión con esto, señala que «por lo que hace al tenor de los poemas en el presente caso (...) hay que recordar que el artículo 10 protege no sólo la sustancia de las ideas e información expresada, sino también la forma en que se transmiten». El carácter estético del arte, referido a creaciones que trascienden el posible mensaje que se quiera transmitir para centrarse en la reflexión formal y estética, abriría así la puerta a lesiones del derecho a la creación artística en los casos en los que se proscribe la difusión de obras esencialmente estéticas. Pese a ello, en el caso la solución se hace derivar finalmente tan sólo del carácter político de los poemas ${ }^{48}$.

Lo mismo sucede a propósito de la publicación de una novela titulada El infierno de Siro basada en hechos reales, sobre la represión militar en el pueblo de Ormaniçi, en Turquía. El autor fue condenado por incitar al separatismo y a la lucha entre los pueblos. Cuando el TEDH estudia el asunto señala que «el libro contiene pasajes en los que se presentan con detalle gráfico detalles del ficticio tratamiento inhumano y las atrocidades cometidas contra los habitantes del pueblo, lo que sin duda crea en la mente del lector una potente hostilidad contra la injusticia a la que los lugareños fueron sometidos en la narración». A esa narración presentada como ficción, sin embargo, le atribuye la capacidad de incitar al odio o a la violencia si se toma literalmente. Con ello viene a rechazar que el discurso ficticio o artístico requiera un análisis diferenciado como ejercicio de la libertad de expresión. En fin, cuando los tribunales franceses identifican las conversaciones mantenidas por unos personajes de ficción en una novela con el

46 STEDH de 8 de diciembre de 1999, en el asunto Karatas c. Turquía (23168/94).

47 Cfr. Freixes Sanjuan, T., «El Tribunal Europeo de Derechos Humanos y las libertades de la comunicación», en Revista de Derecho Comunitario Europeo, n. ${ }^{\circ} 15,2003$, p. 478.

48 Un caso similar a éste es el de la STEDH de 27 de febrero de 2018 en el asunto Sinkova c. Ukraine $(39496 / 11)$. Se trataba de un grupo artístico que fue castigado porque realizando una 'performance' contra el gobierno se puso a freír un huevo en la llama del monumento al soldado desconocido. El TEDH resuelve el asunto concluyendo que la limitación de la libertad de expresión fue justificada. En su decisión no menciona la libertad artística, centrándose en el carácter político del acto. 
pensamiento real de su autor, el TEDH entiende que es un criterio compatible con el artículo 10 del Convenio ${ }^{49}$. Negando cualquier virtualidad autónoma al derecho a la libertad de creación artística, señala expresamente que la única diferencia en los casos de expresión literaria radica en el número de destinatarios que estima menor que los de la prensa, aunque más sostenidos en el tiempo ( $\$ 48)$.

Lo más parecido a un valor específico al arte en la jurisprudencia europea es el reconocimiento de un canon propio específico de enjuiciamiento para la sátira política. Surge a raíz de una exposición realizada en Austria y dedicada a la libertad artística en la que se presentó el cuadro Apocalypse incluyendo un collage de diversas personalidades públicas, políticos y religiosos; las fotos de cuyos rostros se habían pegado sobre cuerpos representados en posturas abiertamente sexuales. A la hora juzgar las restricciones, el TEDH da una especial importancia a la forma utilizada, en un razonamiento muy repetido en decisiones posteriores: «la sátira es una forma de expresión artística y comentario social que exagerando y distorsionando la realidad, pretende provocar y agitar. Por lo tanto, es necesario examinar con especial atención cualquier injerencia en el derecho de un artista —o de cualquier otra persona- a expresarse por este medio» ( $\$ 33)$.

Se desprende de ello que cuando se utiliza una caricatura para expresar una opinión política, el canon utilizable da un margen más amplio a la libertad de expresión. El desarrollo de esta jurisprudencia así lo ratifica, insistiendo en que los personajes públicos deben tener una mayor tolerancia hacia la crítica cuando se expresa de forma satírica. Esta protección acrecentada concurre sólo en la medida en la que se utilice la caricatura o sátira para la crítica política; siempre sometida a algunos límites.

En 2009 el Tribunal ampara con estos mismos argumentos a un ciudadano que hizo un muñeco de guiñol de un político local que implícitamente lo acusaba de financiarse ilegítimamente y lo paseó por la ciudad con motivo de las fiestas de carnaval. Insiste en que el destinatario de las críticas caricaturescas era un hombre político que debía, por ello, ser tolerante a la crítica, en especial a la que se manifiesta en forma de sátira ${ }^{50}$.

La prueba de que esta protección está íntimamente conectada con el contexto político y no se extiende más allá está en el asunto Palomo Sánchez y otros c. España ${ }^{51}$. Unos trabajadores fueron despedidos tras publicar en un boletín sindical la caricatura de algunos trabajadores que apoyaban a la empresa en un contencioso, representados dando sexo oral al director de recursos humanos. El TEDH señala que los límites de la crítica admisible son, ciertamente, menos amplios con respecto a los particulares que con respecto a los políticos y funcionarios y concluye que la caricatura supuso una ofensa a la honorabilidad de las personas realizada a

49 STEDH de 22 de octubre de 2007, en el asunto Lindon, Otchakovsky-Laurens y July c. Francia, § 51.

50 STEDH de 20 de octubre de 2009, en el asunto Alves da Silva c. Portugal (41665/07).

51 STEDH de 12 de septiembre de 2011, en el asunto Palomo Sánchez et al. c. España (28955/06, 28957/06, 28959/06 y 28964/06). 
través de expresiones groseramente insultantes o injuriosas en el seno del medio profesional.

De modo similar se resuelve un asunto relativo a la caricatura publicada en una revista del País Vasco francés con motivo de los atentados del 11 de septiembre en Nueva York. Sobre una imagen de la destrucción de las torres gemelas se había escrito el lema (parodia de un anuncio publicitario de la época) «11-S, todos los soñamos, Hamas lo hizo». El tribunal toma en consideración el estado mundial de shock tras aquel atentado y la situación política en la región en la que se publicó la viñeta. Entiende que su publicación podía atizarla violencia y alterar el orden público, por lo que valida la pena de multa impuesta por el Estado ${ }^{52}$, sin tomar siquiera en cuenta la posible distancia entre la ficción satírica y la realidad.

En la decisión de inadmisión del asunto M'Bala M'Bala c. Francia el tribunal viene a negar directamente el valor específico al discurso artístico. El demandante, un conocido cómico francés, fue condenado y multado por insultos a la comunidad judía a raíz de un espectáculo público, cómico-teatral, en el que se habían incluido observaciones antisemitas. El TEDH niega que el artista haya ejercido su derecho a expresarse a través de la sátira, el humor y la provocación. Cree que se trata de una demostración de odio y antisemitismo, que apoya la negación del Holocausto. En concreto señala que «no podría aceptar que la expresión de una ideología que va contra valores fundamentales del CEDH expresados en su preámbulo, es decir, la justicia y la paz, sea asimilada a un espectáculo, incluso satírico o provocador, que gozara de la protección del art. 10 CEDH».

En definitiva, la protección a la sátira obvia su valor artístico desarrollado mediante la creación de una realidad humorística alternativa, inventada por el autor, y se centra en sus efectos en cuanto mecanismo de crítica política. Esta construcción — similar a la del Tribunal Supremo norteamericano en el asunto de la revista Hustler ${ }^{53}$ — resulta útil a la hora de analizar la función de la libertad de expresión en el sistema de los derechos del Convenio Europeo, pero aporta poca singularidad a la cuestión de la caracterización de la libertad creativa en el mismo.

La cuestión de la autoficción también ha llegado a la jurisdicción europea. Inicialmente lo hace en relación con la novela publicada en Eslovenia Cuando florecen los abedules. Describe la vida de una mujer rural eslovena que emigra a los EE. UU, para volver más tarde a su pueblo, presentándola como una mujer ambiciosa, que usaba el sexo para manipular a su marido y dedicada a la producción clandestina de alcohol. Se menciona también a una de sus hijas, condenada a prisión durante la guerra por robar. Los demandantes encontraron enormes paralelismos con la vida de su propia familia, incluido el apodo con el que se les conocía popularmente. Demandaron a la autora pero la cuestión fue finalmente desestimada. Acuden al TEDH invocando su derecho a la vida privada pero éste respalda la decisión estatal

52 STEDH de 2 octubre de 2008 en el asunto Leroy c. Francia, (36109/03).

53 Sentencia del TS en el asunto Hustler Magazine, Inc. et al. c. Jerry Falwell, 485 U.S. 46 (1988). 
de que la novela presenta una ficción que ha de ser entendida como tal y no como una redacción de hechos reales, por lo que no refleja ninguna intención de ofender. En tal sentido, el Tribunal señala «que el libro en cuestión no se escribió como una biografía, sino como una obra de ficción y, como tal, no tenía por qué se entendido por la mayoría de los lectores como un retrato de gente real» ${ }^{54}$.

La misma cuestión ha vuelto a plantearse en otras ocasiones. Destaca el caso de una escritora portuguesa que se autopublica un libro, con una tirada de cien ejemplares, firmado bajo seudónimo y narrando historias internas de la familia de su marido, con un sesgo claramente negativo ${ }^{55}$. Varios miembros de su familia política presentaron una demanda contra ella que fue rechazada en primera instancia, argumentando el juez que la novela contaba simplemente la historia de la emigración portuguesa a Estados Unidos y las disoluciones familiares resultantes de ello. En segunda instancia fue condena por difamación al entender el tribunal que la historia contada y los personajes pueden ser reconocidos por el público, de modo que no se puede hablar de ficción o de creación artística. Al respecto, el tribunal europeo indica que «la novela es una forma de expresión artística que entra en el terreno de aplicación del art. 10 del Convenio en la medida en que permite participar en el intercambio público de informaciones y de ideas culturales, políticas y sociales de todo tipo. Los que crean una obra, literaria por ejemplo, contribuyen al intercambio de ideas y de opiniones indispensable para una sociedad democrática. Se desprende de ahí la obligación del Estado de no impedir indebidamente su libertad de expresión.» ${ }^{56}$. De ese modo, aún constatando la importancia social de la literatura y el arte, se las sigue encajando por ahora en el régimen general de la libertad de expresión sobre cuestiones de trascendencia social, sin más.

\section{Los casos españoles: la ficción ante el Tribunal Constitucional}

La práctica constitucional española no ha dado lugar por el momento a demasiadas sentencias constitucionales que aborden estas cuestiones. El texto de

54 Decisión de inadmisibilidad de 11 de marzo de 2014, dictada en el asunto Jeľ̌evar y otros c. Eslovenia, (47318/07).

55 Según el resumen de la SETDH, B. es una mujer de mala vida que engaña a su esposo A. Con un físico repugnante, $\mathrm{F}$. es una persona enferma y despreocupada; le quita a su hijo su dinero, va de prostitutas, tiene asuntos extramatrimoniales y muere de SIDA. Su esposa I. es ambiciosa, extravagante, mezquina, calculadora y en conflicto con sus padres y hermanas; abandonando a su esposo F. mientras él está a punto de morir, ella tiene una relación con el hermano de su marido. A. tiene un aire tosco y primitivo. Agente de la PIDE, policía política bajo el régimen de Salazar, su marido, R. ha encarcelado a un centenar de opositores políticos. Su hija, B., es una idiota, una mujer libertina, una libertina y una mala madre. Para finalizar, I. es arrogante, fría, caprichosa, frívola y liviana, ofreciendo su cuerpo a cada hombre abriendo su billetera; está lista para hacer cualquier cosa para hacerse rica, incluso para matar a su padre (F.).

56 STEDH de 12 de marzo de 2015, en el asunto Almeida Leitão Bento Fernandes contra Portugal $(25790 / 11), \S 40$. 
nuestra ley fundamental otorga especial relevancia a la literatura, escindida de lo artístico seguramente como un reflejo de su trascendencia histórica y cotidiana. En efecto, antes del advenimiento de nuevos medios de comunicación, las obras literarias fueron durante siglos la principal fuente de divulgación de ideas y doctrinas. De hecho, la disociación entre lo informativo y lo literario es relativamente reciente; sólo en la modernidad empieza a trazarse una frontera clara en el seno de las obras impresas entre aquellas destinadas a la información cotidiana y las que se centran en la creación literaria. En las primeras constituciones, los límites y restricciones a la información se confunden con toda normalidad con las que se aplican a las obras literarias, y la libertad de imprenta equivale a la de expresión, cubriendo por igual un tipo y otro de productos. Hoy día, sin embargo, la realidad es diferente y lo literario ha de verse como una manifestación más de la expresión artística general, al mismo nivel que la pintura, el cine o la escultura, por poner varios ejemplos.

Sin embargo, por cuestiones materiales, lo cierto es que la noción de lo artístico ha entrado en nuestra jurisprudencia constitucional aplicada a su manifestación literaria. En cualquier caso, la reflexión sobre cómo identificar la obra de arte a efectos de atribuirle su protección específica ha seguido en nuestro país senderos muy similares a los del resto de ordenamientos de nuestro entorno, partiendo de la identificación del bien constitucionalmente protegido. En ese sentido, la especial protección de lo artístico se debe, sin duda, a su capacidad de elevación intelectual, que nos permite reflexionar sobre las circunstancias de la vida con un cierto grado abstracción, superando el caso concreto ${ }^{57}$. Se protege la reflexión vital trascendente y en consecuencia lo que caracteriza al arte en sentido constitucional es el impulso intelectual innovador que se manifiesta en la creación de una obra con un valor reflexivo trascendente ${ }^{58}$. Implica una creación pero también un grado de elevación ${ }^{59}$ que va más allá de la mera exposición documental o la valoración de hechos concretos propias de las libertades de información y expresión respectivamente ${ }^{60}$.

57 El valor del arte en cuanto proceso intelectual es predicable de cualquiera de sus manifestaciones, sin tener que llegar a la intensidad política de lo que algún autor llama «la fuerza emancipadora que la obra de arte y los propios movimientos artísticos han desempeñado a lo largo de la historia», cfr. VÁzQUEZ Alonso, V.J. «Libertad de expresión y religión en la cultura liberal de la moralidad cristiana al miedo postsecular», en Boletín mexicano de derecho comparado, n. ${ }^{\circ} 146,2016$.

58 Algunos autores ponen el acento en el valor crítico del arte, en una definición sugerente pero que, al excluir el elemento creativo producto de la imaginación, no resulta operativa para diferenciar la libertad artística de otras. Vid. García Rubio, M.P., «Arte, religión y Derechos Fundamentales. La libertad de expresión artística ante la religión y los sentimientos religiosos (algunos apuntes al hilo del caso Javier Krahe)», Anuario de Derecho Civil, tomo LXVII, 2014, pp. 397-453.

59 Especialmente interesante en este punto son las consideraciones de la doctrina estadounidense sobre las razones por las que el discurso artístico merece una especial protección. Sobre ello, vid. Díez Bueso, L., op. cit.

60 Resulta ilustrador el asunto tratado en la STC 35/2020, de 25 de febrero. Se trataba de un músico y letrista que había sido juzgado por los comentarios vertidos en una red social. El Tribunal Constitucional 
Este ha sido también el planteamiento del Tribunal Constitucional desde sus primeras decisiones. Así, en un Auto de 1993, se excluye el carácter artístico de un libro de poemas en el que el autor había recogido algunas de las cartas que efectivamente había enviado a la mujer que amaba, quien aparecía identificable en el texto. Más allá del estilo propio del escritor, destacaba el que al agruparlas en una colección indicando que realmente se trata de cartas enviadas a una destinataria identificada, no se trata de crear un nuevo universo de ficción propio, sino de documentar un hecho de la realidad efectivamente sucedido: «al tratarse de la reproducción de cartas de contenido íntimo, publicadas sin autorización de su receptora, de forma que al ser identificable la destinataria por figurar su segundo apellido, así como por el contexto de los escritos, no se puede calificar el libro como 'obra de ficción realizada en forma epistolar' ${ }^{61}$. La consecuencia es que el contenido de las cartas, presentado de esa manera como una exposición de hechos reales puede lesionar el derecho a la intimidad de la persona aludida ${ }^{62}$ de una manera que no lo haría la obra de ficción.

Esta doctrina se pone especialmente de manifiesto a propósito de la publicación del libro «Jardín de Villa Valeria», del escritor M. Vicent. Se trata de un libro de memorias noveladas que bien podría encuadrarse en el espinoso género de la autoficción. En el mismo incluye un párrafo en el que se refiere a una persona realmente existente, imputándole conductas sexuales desordenadas cercanas al adulterio ${ }^{63}$. Fue demandado por la viuda de la persona aludida, que entendió que se lesionaba tanto su honor como su intimidad.

Cuando el asunto llega al Tribunal Constitucional, la primera cuestión a dilucidar es la de si realmente se trataba de un caso de ejercicio de la libertad de creación literaria $^{64}$. Para resolverlo utiliza un criterio aparentemente formal: «Si bien la demandante y algunas de las resoluciones previas han aludido en algún momento a las libertades de información y de expresión, el hecho de tratarse de un fragmento de una novela que cuenta con diversas ediciones permite encuadrarlo sin ningún género de dudas en este derecho fundamental específico, reconocido en la letra b) del art. 20.1 CE» ${ }^{65}$.

evita abordar el asunto — como había hecho confusamente el Tribunal Supremo- con la perspectiva de la creación artística y, ya que se trata de pronunciamientos propios del autor sin pretensión creativa, se limita a un examen desde el punto de vista de la libertad de expresión del art. 20.1 a) CE.

61 ATC 152/1993, de 24 de mayo de 1993, FJ 2.

62 Vid. De Verda y Beamonte, J.R., «Libertad de creación literaria y derecho a la intimidad», Derecho Privado y Constitución, n. ${ }^{\circ} 25,2011$, pp. 137-174.

63 El texto en cuestión rezaba: «Bajo los pinos había jóvenes que luego se harían famosos en la política. El líder del grupo parecía ser Pedro Ramón Moliner, hijo de María Moliner, un tipo que siempre intervenía de forma brillante. Era catedrático de industriales en Barcelona, aparte de militante declarado del PSOE. Tenía cuatro fobias obsesivas: los homosexuales, los poetas, los curas y los catalanes. También usaba un taparrabos rojo chorizo, muy ajustado a las partes. Solía calentarse jugueteando libidinosamente bajo los pinos con las mujeres de los amigos para después poder funcionar con la suya como un gallo».

64 Soler Benito, C., Artes escénicas y derechos de autor, Madrid, 2016, p. 150.

65 STC 51/2008, de 14 de abril, FJ 5. 
A primera vista, se trataría de un criterio insatisfactorio - por formalistasalvo si se entiende que el planteamiento de que 'si es novela, es literatura' no alude exclusivamente a un modo de publicación en forma de libro, sino a un género literario. El formato de novela implica la intención explícita del autor de crear un mundo literario de ficción, antes que de exponer hechos u opiniones sobre la realidad. Quien presenta su obra como un libro de memorias, o como una investigación documental sobre un tema aspira a presentar los hechos narrados como veraces. En cambio, quien anuncia que se trata de una creación literaria da a entender que se trata de una producción artística inventada por él mismo, ya sea de la nada ya a partir de hechos de la realidad pasados por el tamiz de la imaginación.

Aunque el asunto no se abordara en toda su plenitud en sede constitucional, puede recordarse aquí el ejemplo de la película «El Lute, camina o revienta», de Vicente Aranda en la que se narraba la vida de un famoso delincuente. La mujer de éste interpuso una demanda por injurias por los hechos que, a través de su personaje, se le atribuían en la misma. La demanda fue archivada y la recurrente, que se califica a sí misma de quincallera, acudió al Tribunal Constitucional alegando que en las valoraciones de los órganos judiciales sobre la eventual lesión de su honor se habían incluido consideraciones discriminatorias en relación con su raza $\mathrm{u}$ origen social. Aunque el tribunal desestima el recurso por entender que el órgano judicial no había hecho otra cosa que juzgar el honor en el contexto social en el que se emiten los calificativos litigiosos ${ }^{66}$, destaca que en el todo el asunto se da por cierta la posibilidad de que lo narrado en una película supuestamente biográfica afecte a los derechos de la personalidad de las personas representadas en ella, lo que no sucedería si fuera una obra de mera ficción.

La ficción, como se ha comentado a propósito de la experiencia francesa, supone en primer lugar la creación de un mundo propio, que puede estar basado en las vivencias de su autor pero que tiene entidad propia como invención y que no existiría sin su imaginación. En palabras del juez constitucional, «como en toda actividad creativa, que por definición es prolongación de su propio autor y en la que se entremezclan impresiones y experiencias del mismo, la creación literaria da nacimiento a una nueva realidad, que se forja y transmite a través de la palabra escrita, y que no se identifica con la realidad empírica». Así, una novela no pretende describir la realidad ni se limita a presentar la valoración personal del autor sobre la misma. La narración artística nos introduce en un mundo novedoso que no es plenamente identificable con el real, por más que con frecuencia se construya a través de la transformación de referencias de la realidad. Este elemento ontológicamente conectado con lo artístico tiene importantes consecuencias jurídicas, en la medida en que las afirmaciones realizadas en el ámbito de lo imaginario difícilmente pueden traer consecuencias reales. «De ahí que no resulte

66 STC 136/1990, de 19 de julio. 
posible trasladar a este ámbito el criterio de la veracidad, definitorio de la libertad de información, o el de la relevancia pública de los personajes o hechos narrados, o el de la necesidad de la información para contribuir a la formación de una opinión pública libre.»

En efecto, la conclusión de la identificación de la actividad creadora de un mundo propio como definidora de lo artístico es que en este terreno resulta inaplicable el criterio de la veracidad. La ficción es, por definición, ajena al mundo de lo verdadero. La creación protegida constitucionalmente sólo tiene el requisito de ser un instrumento para la elevación de la mente que permita una reflexión personal sobre la naturaleza de la existencia, yendo más allá de la mera descripción de la realidad.

La decisión constitucional es especialmente interesante en el contexto europeo porque además aborda el tema, ya reseñado, de la autoficción.

Como se vio en otros ejemplos, al tratarse del género más fronterizo entre lo artístico y lo documental, la delimitación de estos casos es extremadamente útil para establecer un criterio operativo de distinción. El Tribunal Constitucional es plenamente consciente de la cuestión y la resuelve el valor expansivo de la ficción pues para darle verosimilitud a un mundo nuevo creado por el narrador es necesario con frecuencia añadirle un contexto que evoque la realidad: «el carácter literario de la obra en la que se inserta el pasaje litigioso está fuera de toda duda. Aunque en la misma se hace referencia a personajes, lugares y hechos reales, el género novelístico de la obra y el hecho de no tratarse de unas memorias impiden desconocer su carácter ficticio y, con ello, trasladar a este ámbito las exigencias de veracidad propias de la transmisión de hechos y, por lo tanto, de la libertad de información. Es más, la propia libertad de creación literaria ampara dicha desconexión con la realidad, así como su transformación para dar lugar a un universo de ficción nuevo. En el caso concreto de la novela aquí analizada, las referencias a la generación a la que pertenece el personaje aludido en el pasaje litigioso y a su evolución durante la etapa de la transición política es evidente que no pretenden ser fidedignas, sino que pueden requerir de recursos literarios, como la exageración para cumplir la función que se persigue en la obra. Todo ello encuentra en el derecho a la creación literaria una cobertura constitucional. Y no sólo en el caso del autor del fragmento controvertido, sino también en el de la editorial que ha hecho posible su publicación, sin la cual la obra literaria pierde gran parte de su sentido».

En definitiva, la creación literaria da origen a una obra en la que cabe cierta dosis de exageración incluso en las referencias a personas existentes ${ }^{67}$. Aún así, es razonable pensar que en la medida en que la obra menciona a personajes y circunstancias reales, puede suceder que sus referencias tengan carácter descriptivo, no ficcional.

67 En contra, Gómez Garrido, J., «Derecho al honor y persona jurídica-privada», Revista electrónica del Departamento de Derecho de la Universidad de La Rioja (REDUR), n. ${ }^{\circ}$ 8, 2010, pp. 205-225, que — desde un análisis ciertamente superficial — cree que esta sentencia toma un derrotero peligroso que permitiría afirmaciones vejatorias aunque sean lesivas del honor. 
Es decir, que si una obra literaria recurre a la realidad para dotar de contexto y credibilidad a una narración inventada, en ese punto estará describiendo (es decir, transmitiendo un hecho) o juzgando (expresando un juicio de valor sobre él). En aquella parte de la obra artística en la que haya componente descriptivos de la realidad que puedan ser interpretados como tales por el lector o espectador ${ }^{68}$ resulta jurídicamente posible —y conforme a la Constitución-aplicar el requisito de la veracidad o incluso la prohibición de insultos. Evidentemente, habrá que estar al caso concreto para la delimitación entre la ficción y la realidad: no es igual la libertad del creador para dotar de personalidad ficticia a los protagonistas de su obra que las referencias a personas existentes que aparecen exclusivamente como contexto. La posibilidad de identificar a las personas aludidas ${ }^{69}$ y la manera en que se presenten dando a entender que son realidad o ficción, resultan decisivas en el análisis de cada caso concreto. De cualquier manera, lo relevante es que en términos de principio los mundos imaginarios creados por un autor gozan de un amplio margen en la medida en que no inciden sobre la realidad, sino que la reflejan deformada por la lente de la creatividad.

Estos mismos principios son de aplicación a los supuestos en los que el Tribunal Constitucional se enfrenta a la transmisión de opiniones de manera más o menos creativa realizada a través de un texto impreso. El concepto constitucionalmente protegido de arte exige un empuje intelectual innovador que otorgue a la obra un valor trascendente sobre la mera exposición de hechos u opinión política. Así, cuando tuvo que enfrentarse a columnas de opinión en la prensa escrita que para la crítica política o social se apoyaban en figuras literarias. En tales casos, si la intención del texto es expresar la opinión del autor sobre un elemento concreto de la realidad ha de entenderse que se está ante un ejercicio de la libertad de expresión. Es lo que sucede cuando se trata de un artículo periodístico que «versaba, por medio de un artificio literario, sobre un árbol plantado por la autoridad municipal y algunas supuestas irregularidades con el árbol como pretexto ${ }^{70}$. También en el caso de otro artículo presentado como un ejercicio literario irónico en el que se expresa el juicio de valor de su autor sobre un accidente callejero, su víctima y las responsabilidades municipales correspondientes ${ }^{71}$. El elemento trascedente de la creación artística, pues, no sólo excluye la mera descripción de la realidad, sino también los casos en que — con mayor o menor ornatos estético— se pretenda dar a conocer públicamente un juicio de valor concreto limitado a una situación o posicionamiento específico.

68 Sobre el criterio de la comprensión de un «lector medio», vid. De Verda Beamonte, op. cit., pp. 147 y ss. que lo defiende formalmente aunque en verdad parece referirse con ello al criterio de la identificabilidad de las personas aludidas, que es evidentemente un requisito de procedibilidad necesario.

69 En general, la doctrina civilista suele recalcar la importancia de la posibilidad de identificación de los aludidos, si bien le atribuye un efecto directo en el que parece que no caben obras de ficción que aludan a personas existentes. Por todos, vid. Ammerman Yebra, J., «La Adelaida de El Sur y los límites entre la libertad de creación literaria y los derechos de la personalidad», Revista de Derecho Civil, n. ${ }^{\circ}$ 4, 2016, pp. 167-171.

70 STC 104/1986, de 17 de julio.

71 STC 170/1994, de 7 de junio. 
La protección de la ficción tiene un doble sentido. De una parte, responde al interés constitucional en facilitar la reflexión trascendente sobre cuestiones relacionadas con la existencia humana y la vida en sociedad. De otra parte, es consecuencia del carácter inane respecto a otros bienes de aquello que sucede exclusivamente en el mundo de la ficción ${ }^{72}$. En la medida en que el universo artístico funciona en una dimensión diversa de la realidad, lo que en él se exponga difícilmente puede afectar al honor, la intimidad o la propia imagen de personas realmente existentes ${ }^{73}$. Sin embargo, hay ocasiones en las que se produce un trasvase que conecta ambos mundos. Ya sea, como se ha visto, porque las expresiones presuntamente artísticas no consiguen ese grado de elevación, ya sea porque se acompañan de un contexto real o ya porque la intención última de la obra de la imaginación es incidir directamente sobre la esfera jurídica de personas realmente existentes.

Así, la correcta aplicación de las normas constitucionales sobre creación artística implica realizar una doble operación. En primer lugar, es necesario calificar genéricamente el valor de la obra para crear un universo propio que permita la reflexión trascendental y, en consecuencia, su naturaleza artística. A partir de ahí, aún es posible indagar de una parte la inclusión en la obra de datos inequívocamente presentados como reales y de otra la intención predominante de su autor y la propia incidencia de la obra sobre la realidad. En este último sentido cabe sopesar tanto la intensidad de un eventual daño que se ocasione como, sobre todo, la previsibilidad del mismo.

Es lo que hace el Tribunal Constitucional, notablemente, en el asunto relativo a la difusión de una obra en forma de comic titulada «Hitler=SS». Se trata de la traducción española de un libro, obra del dibujante Vuillemin y el guionista Gourio, que ya tuvo problemas judiciales en Francia, donde llegó a estar secuestrado. En el mismo se pretende realizar una crítica irónica de las actitudes revisionistas del holocausto judío. Sin embargo, para ello se utiliza el recurso de la ironía llevado a un grado extremo en el que se hace una burla descarnada de las víctimas. Cuando el tribunal Constitucional tuvo que analizar el conflicto con los derechos de las víctimas, empezó por constatar el valor artístico-literario del cómic: «se trata de una serie en la que con dibujos y texto se compone un relato, «historieta» o «tebeo» según el Diccionario de la Real Academia, «cómic» en la lengua franca de nuestros días, con una extensión de casi noventa páginas. Por su

72 En el mismo sentido, VÁzQUEz Alonso, V.J. «La libertad de expresión artística una primera aproximación», Estudios de Deusto, n. ${ }^{\circ}$ 62, Bilbao, 2014, 73-92, p. 88.

73 Evidentemente, esto plantea problemas específicos relacionados con los supuestos límites a la expresión con causa en razones de orden público. Así por ejemplo, la cuestión de la obscenidad o la pornografía. No es éste el lugar para desarrollar esta idea pero en la medida en que se trata de limitaciones a discursos sin valor social, el valor artístico debe eximir también de cualquier restricción sustentada en esta causa. Sobre ello, Romero Coloma, A.M., El arte y el derecho: una visión constitucional. Censura, protección jurídica y libertad artística, Madrid, Dickinson, 2017. 
contenido narrativo y su forma compleja, gráfica y literaria, es una obra de ficción, sin la menor pretensión histórica. Por lo tanto, hay que situarlo en principio dentro de una lícita libertad de expresión, en cuya trama dialéctica y su urdimbre literaria se entremezclan ingredientes diversos, con preponderancia del crítico, reflejado en los muy abundantes juicios de valor ${ }^{74}$.

Sin embargo, más allá de la naturaleza artística, la Sala constata también - sobre todo a partir del uso de tópicos y prejuicios racistas- que concurre una intención específica de «humillar a quienes fueron prisioneros en los campos de exterminio» y que busca «deliberadamente y sin escrúpulo alguno el vilipendio del pueblo judío, con menosprecio de sus cualidades para conseguir así el desmerecimiento en la consideración ajena». Independientemente de que se coincida o no con la valoración que hace el juez constitucional de figuras propias del arte como son la exageración o la ironía, lo cierto es que, si se constata que la intención de una obra de ficción no es tanto presentar una reflexión trascendental de su autor como dañar a una persona o colectivo, pierde el sentido constitucional que justificaría su especial protección.

Algo similar sucede con la utilización de la fotografía de un personaje famoso para la elaboración de un fotomontaje humorístico en un semanario humorístico cuando lo que se persigue no es una creación artística sino, simplemente, un gesto de mofa personal ${ }^{75}$ : no es necesario entrar siquiera a valorar la vertiente creativa del montaje, pues es evidente que sólo responde a una intención opinativa que carece de protección constitucional cuando no versa sobre cuestiones con relevancia social.

Así, la conexión entre ficción y realidad (ya sea por la inclusión de datos reales, ya por el uso intencional de la obra) supone una quiebra de la naturaleza artística que implica que jurídicamente sean de aplicación las mismas reglas que valen para las libertades de información y expresión. La experiencia demuestra que ello puede suceder mediante caricaturas que afecten al derecho al honor, películas que dañen la propia imagen, escritos lesivos de la intimidad y toda una amplia gama de opciones. Lo que define a la creación artística no es el formato físico elegido, que puede ser utilizado también con otras finalidades, sino una específica voluntad creativa concentrada en la innovación en sí misma y que como tal adquiere trascendencia intelectual.

\section{CONCLUSIÓN}

La autonomía conceptual del derecho a difundir la creación científica y artística implica su reconocimiento como discurso protegido. En ese marco conceptual, la identificación de lo artístico en nuestro sistema sigue pautas muy similares

74 STC 176/1995, de 11 de diciembre, FJ 2.

75 Es el caso abordado en la STC 23/2010, de 27 de abril, FJ 5. 
a las de los ordenamientos de nuestro entorno que optan por reconocer tal singularidad.

De hecho, la experiencia del Tribunal Europeo de Derechos Humanos pone de manifiesto las dificultades prácticas de una noción de libertad de expresión que pretenda cubrir cualquier manifestación comunicativa pero se oriente esencialmente a la protección la discusión política y sobre cuestiones de relevancia pública. Incluso desde la visión del derecho como principio - antes que como regla - que caracteriza a la jurisprudencia europea resulta imposible negligir la necesidad de proteger los valores específicos de la creación artística.

El elemento creativo implica que lo artístico reflexiona sobre la realidad a partir de universos novedosos que surgen de la imaginación del autor y a los que resulta imposible aplicar las normas que rigen la difusión de contenido centrados en lo real, ya sean factuales u opinativos. En el estricto ámbito de la ficción artística (en cualquiera de sus manifestaciones, desde la pintura o la danza hasta la alta costura) el interés público en proteger esa elevación intelectual trascendente raramente se enfrenta a la posibilidad de lesionar otros bienes jurídicamente protegidos. Sin embargo, del mismo modo que no hay información sin opinión (y viceversa) tampoco hay arte sin referencias a la realidad. El deslinde en cada caso entre la creación propia del autor y la reproducción documental o la valoración directa de la realidad es imprescindible para aplicar la regla constitucional que protege la difusión artística.

$$
* * *
$$

TITLE: Artistic Freedom as a protected speech: Comparative experiences and Spanish possibilities

ABSTRACT: Freedom of artistic creation includes the liberty to disseminate artistic works. The protection of the artistic expression is related with the possibility of distinguishing fiction and reality. This paper studies the possibilities and limits of the art as a protected speech in Spain, taking into account the examples of France, Germany and the European Court of Human Rights.

Resumen: La libertad de creación artística incluye la facultad de difundir las obras artísticas. La protección de la expresión artística se articula en torno a la distinción entre ficción y realidad. El trabajo estudia las posibilidades y límites del arte como discurso protegido en España tomando en cuenta los ejemplos de Francia, Alemania y el Tribunal Europeo de Derechos Humanos.

KEY WORDS: Artistic freedom, free speech, privacy, fuction, novel.

Palabras Clave: Libertad artística, libertad de expresión, vida privada, ficción, novela.

FECHA DE RECEPCIÓN: 12.05.2020

FECHA DE ACEPTACIÓN: 09.09.2020 